\title{
Utilization of Dredged Sediments from Lumsai Canal with Rice Husks to Produce Bricks
}

\author{
W. Tangprasert, S. Jaikaew, and N. Supakata
}

\begin{abstract}
The laboratory-scale study was conducted to assess the feasibility of using dredged sediments from Lumsai canal with rice husks to produce bricks. This study was investigated into three different proportions of dredged sediments with rice husks ranging from $0,5,10,15$, and 20 percent (by weight of rice husks or rice straws) as raw materials in producing bricks. The characteristics of the dredged sediments, rice husks, and fired bricks were analyzed using X-ray fluorescence (XRF) and X-ray diffraction (XRD), respectively. The physical-mechanical properties of fired bricks were found to comply with the criteria for bricks (Thai Industrial Standards 77-2545). The obtained results indicated that major chemical compositions of dredged sediments were silica $\left(\mathrm{SiO}_{2}\right) 56.27$ percent, alumina $\left(\mathrm{Al}_{2} \mathrm{O}_{3}\right) \mathbf{1 1 . 7 6}$ percent and iron oxide $\left(\mathrm{Fe}_{2} \mathrm{O}_{3}\right) 7.84$ percent, and heavy metal contents including $\mathrm{Cr}, \mathrm{Cu}, \mathrm{Zn}, \mathrm{As}, \mathrm{Cd}, \mathrm{Hg}, \mathrm{Pb}, \mathrm{Mn}, \mathrm{Sr}$, and $\mathrm{Ni}$ were lower than the soil quality standard. Results of this study showed that bricks made from dredged sediments with 5 percent of rice husks were suitable as primary raw materials in the production of bricks without harmfulness.
\end{abstract}

Index Terms -Bricks, dredged sediments, rice husks.

\section{INTRODUCTION}

Lumsai canal is located in Nong Chok District, Bangkok and flows into Chao Phraya River. Bangkok Administration Metropolitan is responsible for maintaining of the Watsongpeenong canal by dredging the sediments from the bottom of this canal. Dredged sediments with annually approximately hundred millions of tons are generated in worldwide [1], [2]. Many studies show that sediment from river can be used in the production of bricks as the natural clay replacement that comply with construction standard [3]-[10].

The main objective of the present study was to investigate the feasibility of using dredged sediments from Lumsai canal, Nong Chok District, Bangkok together with rice husks to produce brick. Bricks made from dredged sediments mixed with rice husks were discussed in terms of physical-mechanical properties and microstructure.

Manuscript received May 10, 2014; revised July 8, 2014

W. Tangprasert and S. Jaikaew were with the Department of Environmental Science, Faculty of Science, Chulalongkorn University, Bangkok 10330 Thailand (e-mail: ryumi_mars@hotmail.com, toey.siritorn@gmail.com).

N. Supakata is with the Department of Environmental Science, Faculty of Science, Chulalongkorn University, Bangkok 10330 Thailand (e-mail: nuta.s@chula.ac.th).

\section{EXPERIMENTAL}

\section{A. Characterization of Dredged Sediments and Rice Husks}

Dredged sediments were gained from Lumsai Canal, Nong Chok District, Bangkok (13²9'24" N 100 30' 0" E) flows into Chao Phraya River. The collected dredged sediments had agglomerated and were therefore ground into smaller size by using grounder (TBSN-330).

Rice husks were obtained from Koiruttakwa community, Nong Chok District, Bangkok. Rice husks were ground and sieved into particles with size between $2 \mathrm{~mm}$ for using in experiments.

The chemical analysis of the dredged sediments, rice husks, and rice straws was determined by $\mathrm{X}$-ray fluorescence analysis (XRF, Bruker model, S8 Tiger). Crystalline minerals were identified by X-ray Diffraction (XRD, Bruker AXS Model, D8-Discover).

\section{B. Preparation of Sediment Specimen and Sintering Operation Procedure}

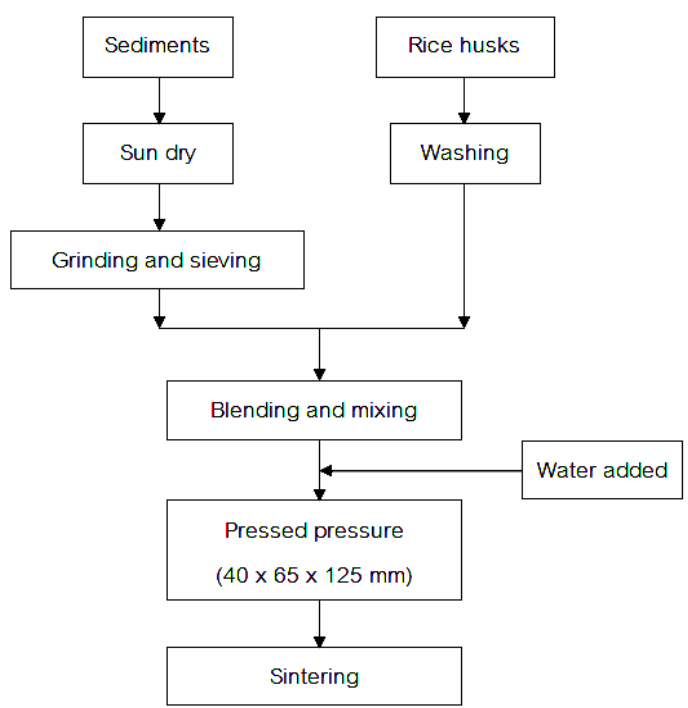

Fig. 1. Simple preparation process

In this study, five different proportions of rice husks were added to dredged sediments: $0 \%$ rice husks and 100\% sediments (R0); $5 \%$ rice husks and 95\% sediments (R5); $10 \%$ rice husks and $90 \%$ sediments (R10); $15 \%$ rice husks and $85 \%$ sediments (R15) and $20 \%$ rice husks and $80 \%$ sediments (R20). The dredged sediments and rice husks were blended, and the water content of $20 \%$ by mass was added to the mixtures to form plasticity. After mixing, the mixtures were molded using iron mold under at $76 \mathrm{kgf} / \mathrm{cm}^{2}$ by using a hydraulic press to form full-brick $\left(6.5 \times 12.5 \times 4.0 \mathrm{~cm}^{3}\right)$. 
Then the shaped specimens were removed from the molds approximately three day after casting and were allowed to dry in the air. The dried bricks were then fired at $700{ }^{\circ} \mathrm{C}$. The sample preparation process was summarized in Fig. 1.

\section{Characterization of Fired Brick}

For water absorption test, the specimens were dried in an oven $110^{\circ} \mathrm{C}$ for 24 hours and then placed to cool down in the air until their weight were constant (dry weight, $W_{d}$ ). Then the specimens were immersed in water for 24 hours in room temperature (wet weight, $W_{w}$ ). The water absorption was calculated from $\left[W_{w}-W_{d} / W_{d}\right] \times 100$.

The compressive strength was determined, using compression machine (Amsler 20 ton) on test samples with full-brick size $\left(6.5 \times 12.5 \times 4.0 \mathrm{~cm}^{3}\right)$.

The micro-structures of the sintered specimens were examined using scanning electron microscopy (SEM, JSM-6400). Crystalline phases were identified by XRD (XRD, Bruker, D8).

\section{Life Cycle Assessment (LCA) of Fired Brick}

Life cycle assessment (LCA) is an approach to evaluate and improve the environmental impact of products (Finnveden et al., 2009). According to ISO 14042, there are 4 steps of LCA including goal and scope definition, inventory analysis, impact assessment, and interpretation. In the present study, the life cycle assessment (LCA) methodology is implemented in the facing bricks production in laboratory in term of cradle-to-gate. The scopes of cradle-to-gate are studied and collected information in 2 processes including raw material acquisition and manufacturing using Sima Pro 7.1 program from National Metal and Materials Technology Center for calculation. Five impact categories are considered: global warming, ozone layer depletion, human toxicity, acidification, and eutrophication.

\section{RESULTS AND DisCUSSION}

\section{A. Characterization of Dredged Sediments}

\begin{tabular}{ccc}
\multicolumn{3}{c}{ TABLE I: CHEMICAL COMPOSITION OF THE DREDGED SEDIMENTS } \\
\hline \hline $\begin{array}{c}\text { OXIDE CONTENT } \\
(\mathrm{WT} . \%)\end{array}$ & $\begin{array}{c}\text { DREDGED } \\
\text { SEDIMENTS }\end{array}$ & $\begin{array}{c}\text { HEAVY METAL STANDARD } \\
(\mathrm{PCD}, 2004)^{*}\end{array}$ \\
\hline $\mathrm{SIO}_{2}$ & 56.27 & \\
$\mathrm{AL}_{2} \mathrm{O}_{3}$ & 11.76 & \\
$\mathrm{FE}_{2} \mathrm{O}_{3}$ & 7.84 & \\
$\mathrm{SO}_{3}$ & 3.03 & \\
$\mathrm{~K}_{2} \mathrm{O}$ & 2.29 & \\
$\mathrm{MGO}$ & 1.85 & \\
$\mathrm{CAO}$ & 1.81 & \\
$\mathrm{TIO}_{2}$ & 0.99 & \\
$\mathrm{NA}_{2} \mathrm{O}$ & 0.35 & $0.18(\mathrm{MN})$ \\
$\mathrm{P}_{2} \mathrm{O}_{5}$ & 0.18 & $0.04(\mathrm{~PB})$ \\
$\mathrm{CD}$ & $<0.01$ & \\
$\mathrm{~PB}$ & $<0.01$ & $0.03(\mathrm{ZN})$ \\
$\mathrm{AS}$ & 0.01 & $0.03(\mathrm{CR})$ \\
$\mathrm{CU}$ & 0.02 & \\
$\mathrm{ZN}$ & 0.03 & \\
$\mathrm{CR}$ & $<0.01$ & \\
$\mathrm{HG}$ & $<0.01$ & \\
\hline
\end{tabular}

*Soil quality standards for residential and agricultural use (PCD, 2004)

The data of the chemical composition of dredged sediments in oxide form is shown in Table I. It could be observed that $\mathrm{SiO}_{2}$ is the predominant oxide in dredged sediments followed by $\mathrm{Al}_{2} \mathrm{O}_{3}, \mathrm{Fe}_{2} \mathrm{O}_{3}, \mathrm{SO}_{3}, \mathrm{~K}_{2} \mathrm{O}, \mathrm{MgO}$, and $\mathrm{CaO}$. As a result, dredged sediments could be used to produce bricks because $\mathrm{SiO}_{2}$ supported the shape and the strength of the brick body [11]. A significant amount of $\mathrm{Fe}_{2} \mathrm{O}_{3}(4.53 \mathrm{wt} \%)$ in the dredged sediment may contribute to the reddish color of the fried bricks. The high contents of fluxing oxides, such as $\mathrm{MgO}, \mathrm{CaO}, \mathrm{K}_{2} \mathrm{O}$ and $\mathrm{Na}_{2} \mathrm{O}$, could reduce the sintering temperature [12].

The amount of heavy metals in dredged sediments could be an indicator of toxicity in environment. The concentrations of the heavy metals were presented in Table I. As a result, it showed that the heavy metals in raw materials were below the thresholds prescribed in Soil Quality Standard of Pollution Control Department [13]. Therefore, dredged sediments could be used as raw materials for producing bricks without harmfulness.

\section{B. Characterization of Fired Brick}

Five different proportions of rice husks added to dredged sediments: $0 \%$ rice husks and $100 \%$ sediments (R0); $5 \%$ rice husks and 95\% sediments (R5); $10 \%$ rice husks and $90 \%$ sediments (R10); $15 \%$ rice husks and $85 \%$ sediments (R15) and $20 \%$ rice husks and $80 \%$ sediments (R20) after firing were shown in Fig. 2. The appearance of fired brick samples showed that all fired brick samples were not crack or broken.

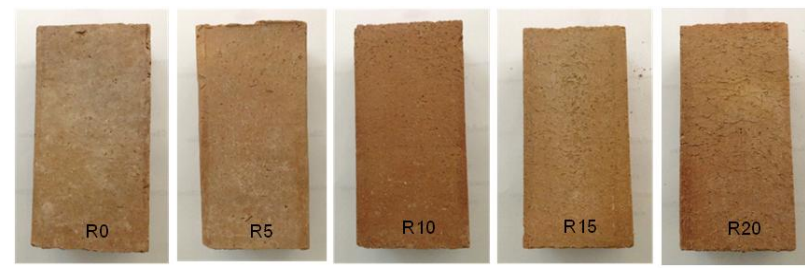

Fig. 2. Fired bricks made from dredged sediments and rice husks.

\section{1) Bulk density}

The bulk densities of fired brick samples are given in Table II. These were greater than $1.50 \mathrm{~g} / \mathrm{cm} 3$ for samples containing $0 \%$ and $5 \%$ rice husks. Bulk density decreased with increasing rice husks addition. The higher contents of rice husks addition, the lower the porosity and shorter the path among particles for the diffusion of gases. Hence, a higher rice husks addition ratio increases the open pore volume and decreases the bulk density of fired brick samples [14].

TABLE II: BULK DENSITY OF FIRED BRICK SAMPLES

\begin{tabular}{cc}
\hline TREATMENTS & BULK DENSITY $\left(\mathrm{g} / \mathrm{cm}^{3}\right)$ \\
\hline R0 & $1.57 \pm 0.07$ \\
R5 & $1.53 \pm 0.04$ \\
R10 & $1.41 \pm 0.03$ \\
R15 & $1.27 \pm 0.02$ \\
R20 & $1.13 \pm 0.03$ \\
\hline \multicolumn{2}{c}{ 0\% rice husks, R5: 5\% rice husks, R10: $10 \%$ rice husks, R15: $15 \%$ rice } \\
husks, R20: $20 \%$ rice husks
\end{tabular}

\section{2) Water absorption}

As shown in Fig. 3, the water absorption increased as more rice husks was added. Thus, the addition of rice husks significantly increased the open porosity. According to TIS77-2545, for a good quality brick, the water absorption 
should be less than $25 \%$. Thus, fired bricks produced from dredged sediments with $0 \%, 5 \%$, and $10 \%$ of rice husks could meet the requirements of water absorption for good quality bricks.

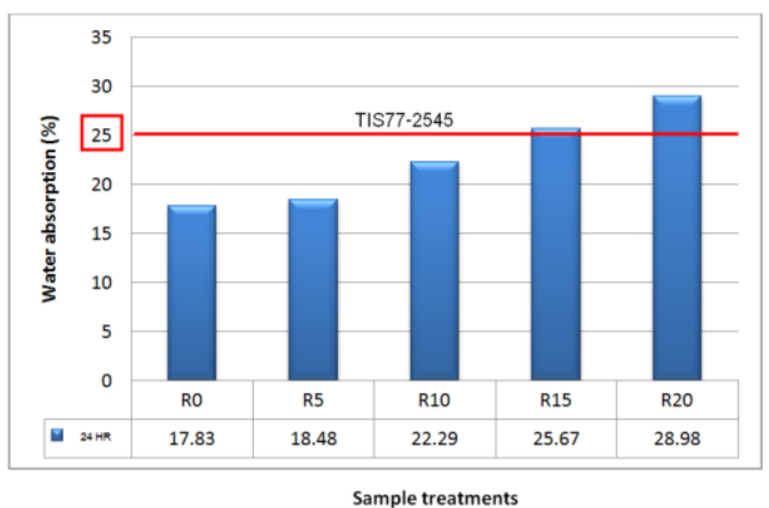

Fig. 3. Water absorption (\%).

\section{3) Compressive strength}

The compressive strength of fired bricks was shown in Fig 4. The results indicated that the compressive strength was affected by the different rice husks percentage addition, with higher compressive strength values being related to lower rice husks contents. Dredged sediments had high amount of silica that could be strengthen the strength of the fired bricks [11]. According to TIS77-2545, the compressive strength of good quality bricks must be above $7 \mathrm{MPa}$. The compressive strength of bricks with $0 \%$ and 5\% rice husks were 9.04 and $8.02 \mathrm{MPa}$, respectively. Thus, the fired bricks with $0 \%$ and $5 \%$ rice husks could comply with the requirements of compressive strength for good quality bricks.

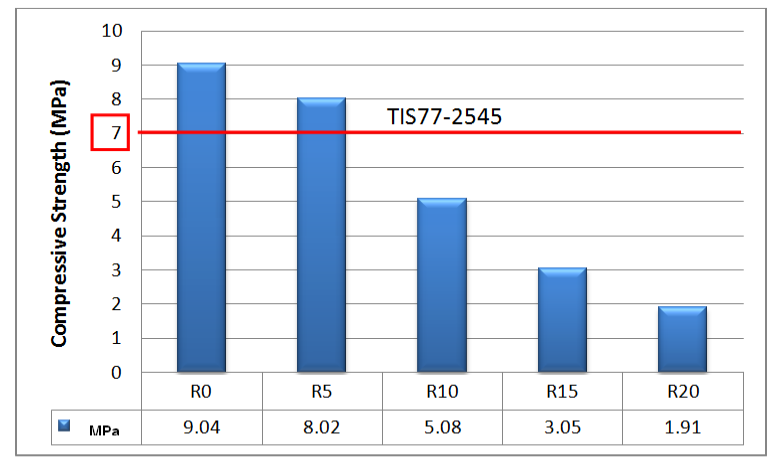

Sample treatments

Fig. 4. Compressive strength of the fired bricks.

The water absorption and compressive strength of the fired brick samples are the important factors in considering their application as construction bricks. Increasing the number of open pores in the fired brick samples implies and increase in water absorption and decrease in bulk density and compressive strength.

\section{4) Micro-structure analysis}

Fig. 5 shows the SEM micrographs of fired brick samples at $700{ }^{\circ} \mathrm{C}$ with different amounts of added rice husks. As shown in Fig. 5, with $0 \%$ rice husks, the fired brick samples produced dense matrix material with good surface characteristics. These results are in agreement with the low water absorption, high compressive strength and bulk density

of fired brick samples. The highest amount of macro-pores and smaller particles were observed in bricks with $20 \%$ rice husks, which adversely affect the compressive strength of bricks, due to the excessive burning of organic matter [2].

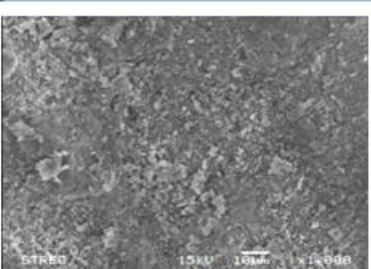

(a) $0 \%$ rick husks $(\times 1000)$

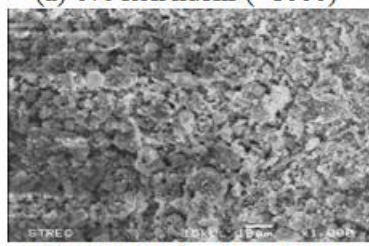

(c) $10 \%$ rick husks $(\times 1000)$

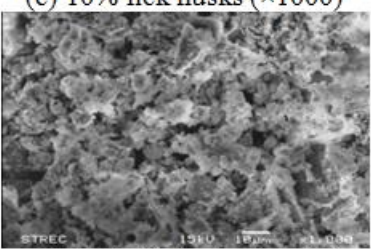

(e) $20 \%$ rick husks $(\times 1000)$

Fig. 5. Scanning electron micrograph images of fired brick samples: (a) $0 \%$ rice husks, (b) $5 \%$ rice husks, (c) $10 \%$ rice husks, (d) $15 \%$ rice husks, (e) $20 \%$ rice husks.

\section{5) Life cycle assessment (LCA) of fired brick}

The environmental impact of the facing brick production process in term of cradle-to-gate; raw material and manufacturing are evaluated by using life cycle assessment methodology. The LCA methodology in this study is gained from Sima Pro 7.1 program calculation. Four impact categories are considered: global warming, human toxicity, acidification, and eutrophication. The results showed the high values of environmental impacts of facing brick production were global warming, human toxicity, acidification, eutrophication, and ozone layer depletion, consecutively. Most of the emissions to the environment are attributed to the energy use, directly from combustion fuel and indirectly from electricity usage in laboratory during burning process as shown in Fig. 6.

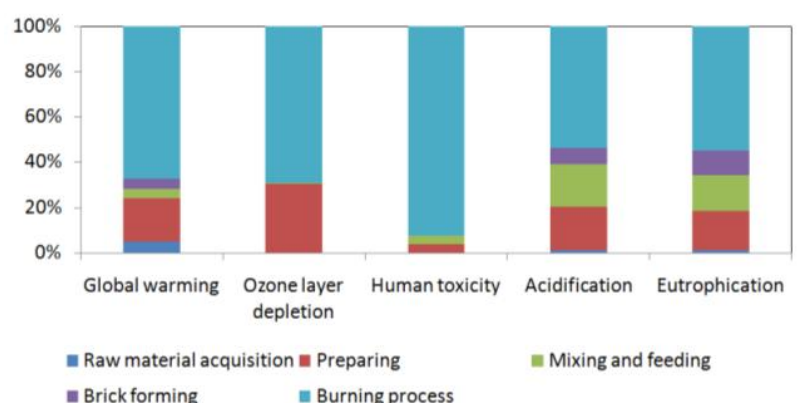

Fig. 6. Distribution of environmental impact in producing 1 piece of fired brick from dredged sediments mixed with rice husks.

\section{CONCLUSION}

Soil texture of Lumsai canal sediment was clay. Major 
chemical compositions were silica $\left(\mathrm{SiO}_{2}\right) 56.27$ percent, alumina $\left(\mathrm{Al}_{2} \mathrm{O}_{3}\right) 11.76$ percent and iron oxide $\left(\mathrm{Fe}_{2} \mathrm{O}_{3}\right) 7.84$ percent and Heavy metal contents were lower than the soil quality standard. Bricks made from dredged sediments from Lumsai canal with 5 percent of rice husks was suitable as primary raw materials in the production of bricks without harmfulness, which had low percentage of water absorption (18.48 percent), high resistance pressure $(8.02 \mathrm{Mpa})$, and had dimensions and tolerances in range of standard criterion. In addition, the results showed that increasing rice husks will decrease bulk density and compressive strength of brick specimens while water absorption will be increased.

\section{ACKNOWLEDGMENT}

This research has been supported by National Research University Project, Office of Higher Education Commission (WCU-047-CC-57). The authors also would like to thank The King's Royally Initiated Leam Phak Bia Environmental Research and Developmental Project (the Royal LERD project) and National Metal and Materials Technology Center for providing the collaboration in this work.

\section{REFERENCES}

[1] V. Dubois, N. E. Abriak, R. Zentarand, and G. Ballivy, "The use of marine sediments as a pavement base material," Waste Management, vol. 29, no. 2, pp.774-782, 2009.

[2] Y. Xu, C. Yan, B. Xu, X. Ruan, and Z. Wei, "The use of urban river sediments as a primary raw material in the production of highly insulating brick," Ceramics International, vol. 40, pp. 8833-8840, 2014.

[3] M. Samara, T. Lafhaj, and C. Chapiseau, "Valorization of stabilized river sediments in fired clay bricks: factory scale experiment," Journal of Environmental Management, vol. 163, pp. 701-710, 2009.

[4] M. C. Casado-Martínez, J. L. Buceta, M. J. Belzunce, and T. A. DelValls, "Using sediment quality guidelines for dredged material management in commercial ports from Spain," Environment International, vol. 32, pp. 388-396, 2006.

[5] R. J. Collins, "Dredged silt as a raw-material for the construction industry," Resource Conservation and Recovery, vol. 4, no. 4, pp. 337-362, 1980

[6] K. Hamer and V. Karius, "Brick production with dredged harbour sediments an industrial-scale experiment," Waste Management, vol. 22, pp. 521-530, 2002.

[7] M. Karpuzcu, D. Buktel, and Z. S. Aydin, "The dewaterability, heavy metal release and reuse characteristics of Golden Horn surface sediment," Water Science and Technology, vol. 34, pp. 365-374, 1996.
[8] Z. Lafhaj, M. Samara, F. Agostini, L. Boucard, F. Skoczylas, and G. Depelsenaire, "Polluted river sediments from the North region of France: Treatment with Novosol process and valorization in clay bricks," Construction and Building Materials, vol. 22, pp. 755-762, 2008.

[9] M. Romero, A. Andrés, R. Alonso, J. Viguri, and J. Ma Rincón, "Sintering behavior of ceramic bodies from contaminated marine sediments," Ceramics International, vol. 34, pp. 1917-1924, 2008.

[10] P. Torres, R. S. Manjate, H. R. Fernandes, S. M. Olhero, and J. M. F. Ferreira, "Incorporation of river silt in ceramic tiles and bricks," Ceramics International, vol. 1, pp. 5-12, 2009.

[11] C. Y. Lin, M. Wu, J. A. Bloom, I. J. Cox, and M. Miller, "Rotation, scale, and translation resilient public watermarking for images," IEEE Trans. Image Process., vol. 10, no. 5, pp. 767-782, May 2001.

[12] A. Mezencevova, N. Yeboah, S. Burns, L. Kahn, and K. Kurtis, "Utilization of Savannah Harbor river sediment as the primary raw material in production of fired brick," Waste Management, vol. 113 pp. 128-136, 2012

[13] V. Loryuenyong, T. Panyachai, K. Kaewsimork, and C. Siritai, "Effect of recycled substitution on the physical and mechanical properties of clay bricks," Waste Management, vol. 29, pp. 2717-2721, 2009.

[14] Pollution Control Department, Soil Quality Standards for Residential and Agricultural Use, Ministry of Natural Resources and Environment, 2004.

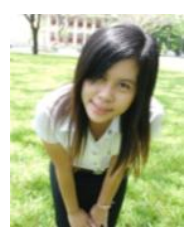

Wipawan Tangprasert is a B.S. candidate of environmental science in the Department of Environmental Science, Faculty of Science, Chulalongkorn University.

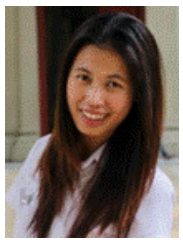

Siridhorn Jaikaew is a B.S. candidate of environmental science in the Department of Environmental Science, Faculty of Science, Chulalongkorn University.

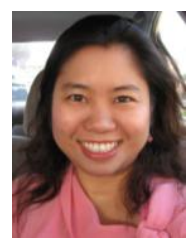

Nuta Supakata got the Ph.D. degree in environmenta science from College of Environment, Kasetsart University, Thailand in 2011. She is a lecturer of the Department of Environmental Science, Faculty of Science, Chulalongkorn University. 